\title{
Assessment of Trace Element Levels in Muscle Tissues of Fish Species Collected from a River, Stream, Lake, and Sea in Sakarya, Turkey
}

\author{
Tülay Küpeli, Hüseyin Altundağ, and Mustafa İmamoğlu \\ Chemistry Department, Faculty of Arts and Science, Sakarya University, 54187 Sakarya, Turkey \\ Correspondence should be addressed to Hüseyin Altundağ; haltundag@yahoo.com
}

Received 21 August 2013; Accepted 18 December 2013; Published 24 March 2014

Academic Editors: G. El-Chaghaby and M. El-Shahat

Copyright (c) 2014 Tülay Küpeli et al. This is an open access article distributed under the Creative Commons Attribution License, which permits unrestricted use, distribution, and reproduction in any medium, provided the original work is properly cited.

Levels of some trace and essential elements, including $\mathrm{Al}, \mathrm{B}, \mathrm{Ba}, \mathrm{Cr}, \mathrm{Cu}, \mathrm{Fe}, \mathrm{Mn}, \mathrm{Ni}, \mathrm{Sr}$, and $\mathrm{Zn}$, were determined in 17 different fish species from Sakarya River, Çark Stream, Sapanca Lake, and Western Black Sea using ICP-OES after microwave (MW) digestion procedure. During preparation of samples for analysis, wet and MW digestion methods were also compared. Accuracy of the digestion methods was checked by the analysis of DORM-3 reference material (Fish Protein Certified Reference Material for Trace Metals). Concentrations of trace elements were found as Al: 6.5-48.5, B: 0.06-3.30, Ba: 0.09-2.92, Cr: 0.02-1.64, Cu: 0.13-2.28, Fe: 7.28-39.9, Mn: 0.08-11.4, Ni: 0.01-26.1, Sr: 0.17-13.5, and Zn: 11.5-52.9 $\mu \mathrm{g} \mathrm{g}^{-1}$. The obtained results were compared with other studies published in the literature. Trace element levels in various fish species collected from waters in Sakarya region were found to be below limit values provided by Turkish Food Codex (TFC), Food and Agriculture Organization (FAO), and World Health Organization (WHO).

\section{Introduction}

It is significantly important to determine and monitor heavy metal levels in foodstuffs, particularly seafood, because heavy metal ions can easily accumulate in such food compared to other foodstuffs and cause harmful effects on human health $[1,2]$. Discharge of industrial waste water without a pretreatment into lakes, rivers, stream, and sea primarily causes an increase in heavy metal ion concentration in such water environments. Moreover, such waters are speedily polluted by chemical substances, paints, petroleum products, and industrial, domestic, and modern agriculture wastes [3, 4]. Metal pollutants in the form of particles, metal ions, and organic and inorganic compounds in water also toxify the associated ecosystem $[5,6]$. Potential of heavy metal ions to accumulate in seafood, including fish living in waters polluted with heavy metals, is rather high. Heavy metals, which especially accumulate in organs of fish, such as internal organs, kidneys, and spleen, can be transmitted to and accumulated in various organs of human body by their consumption [ 5 , 7]. Therefore, introduction of heavy metals into food chain threatens human health. On the other hand, fish is one of the most important foods to be eaten for a healthy life because it has a high protein quality and nutritional value [8]. However, it is suggested worldwide that fish and seafood are consumed more in order to prevent cardiovascular diseases and some other diseases. Fish is especially recommended to infants, elderly, cardiac patients, those who had a brain hemorrhage, and those experiencing digestion problems because it has high mineral content and low energy level [9]. Although consumption of fish and seafood is useful for human health, it may cause toxic effects by transmission into human body by food of heavy metal ions as a result of accumulation in fish's body of pollutants that may be present in water and cause a risk for human health $[10,11]$.

Although Turkey is surrounded on three sides by the sea, the amount of seafood consumed per capita is low and mainly concentrates in coastal regions. However, despite this, fish consumption has increased in recent years [12]. Annual average amount of seafood consumed per capita was $5 \mathrm{~kg}$ until 2004 and increased in 2012 by $80 \%$ to $9 \mathrm{~kg}$ [13], which is still below $12 \mathrm{~kg}$ per capita recommended by WHO [14]. 
In this study, levels of some trace elements, including $\mathrm{Al}, \mathrm{B}, \mathrm{Ba}, \mathrm{Cr}, \mathrm{Cu}, \mathrm{Fe}, \mathrm{Mn}, \mathrm{Ni}, \mathrm{Sr}$, and $\mathrm{Zn}$, were measured by ICP-OES in 17 different fish species caught in the waters of Sakarya River, Çark Stream, Sapanca Lake, and Western Black Sea during September and October, 2012. Wet and MW digestion techniques were compared for preparation of fish samples to measurement step by ICP-OES. Accuracy of these methods was checked by the analysis of DORM-3, a certified reference material (Fish Protein Certified Reference Material for Trace Metals). The results were discussed by comparing with previous studies reported in the literature as well as standard values in Turkish Food Codex (TFC), Food and Agriculture Organization (FAO), and World Health Organization (WHO).

\section{Material and Method}

2.1. Preparation of Samples for Analysis. 24 samples were collected from 17 different fish species caught in the waters of Sakarya River, Çark Stream, Sapanca Lake, and Western Black Sea within the borders of the province of Sakarya during September and October, 2012. Fish species were Silurus glanis, Blicca bjoerkna, Capoeta pestai, Cyprinus carpio, Scardinius erythrophthalmus, Mugil cephalus, Barbus capito, Esox lucius, Tinca tinca, Trachurus mediterraneus, Sarda sarda, Mullus barbatus, Engraulis encrasicolus, Gobius niger, Merlangius merlangus, Belone belone, and Pomatomus saltatrix. Internal organs, head, tail, and scales of fish samples were cleaned using a stainless-steel knife; muscle tissues obtained were washed with ultradistilled water and dried using filter paper. The samples were dried in drying oven at $110^{\circ} \mathrm{C}$ for approximately 4 hours, homogenized in a porcelain mortar, and kept in polyethylene bags at $-20^{\circ} \mathrm{C}$ until the day of analysis. The studied area are shown in Figure 1.

2.2. Reagents. Glass and plastic containers used in the study were allowed to stand in a $10 \% \mathrm{HNO}_{3}$ solution overnight and rinsed using ultradistilled water (Milli-Q Millipore $18.2 \mathrm{M} \Omega \cdot \mathrm{cm}$ ). All reagents used in the analysis are analytical or of higher grade. Suprapur nitric acid $(65 \%, \mathrm{w} / \mathrm{w})$, suprapur hydrochloric acid $(37 \%, w / w)$ and analytical grade hydrogen peroxide $(30 \%, w / w)$, were purchased from Merck (Germany). All solutions used in the study were prepared using ultradistilled water. ICP multielement standard solution of $1000 \mathrm{mg} \mathrm{L}^{-1}$ supplied by Merck was used after step-by-step dilution. Accuracy and precision of the results of the samples were checked using standard reference material (CRM, DORM-3) supplied from the National Research Council of Canada (CNRC).

2.3. Instruments. ICP-OES (inductively coupled plasmaoptical emission spectrometer, Spectro Analytical Instruments, Kleve, Germany) was used for the determination of concentration of elements. The experimental conditions used on ICP-OES are given in Table 1. Milestone Ethos D MW closed system (maximum pressure $1450 \mathrm{psi}$, maximum temperature $300^{\circ} \mathrm{C}$ ) was used to digest fish muscle samples, whereas IKA RCT classic model heater with magnetic stirrer was used to digest samples by wet decomposition procedure.

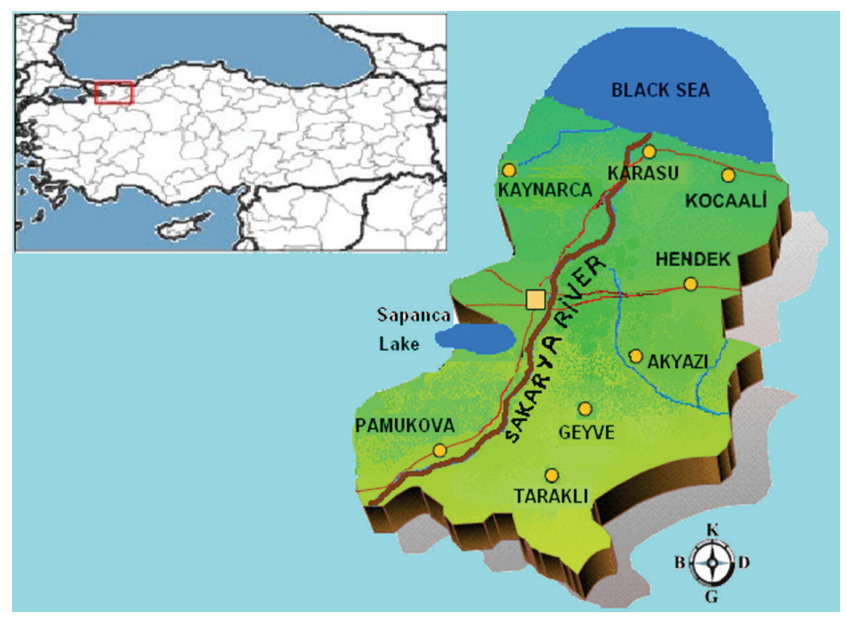

FIGURE 1: The map showing the sampling area.

TABLE 1: Instrumental analytical conditions of element analyses.

\begin{tabular}{lc}
\hline Instrument & Conditions \\
\hline ICP-OES & \\
RF power & $1450 \mathrm{~W}$ \\
Auxiliary argon flow rate & $0.7 \mathrm{~L} \mathrm{~min}^{-1}$ \\
Plasma gas flow & $13 \mathrm{~L} \mathrm{~min}^{-1}$ \\
Nebulizer flow & $0.8 \mathrm{~L} \mathrm{~min}^{-1}$ \\
Nebulizer & Modified Lichte \\
Spray chamber & Cyclonic \\
Sample aspiration rate & $2.0 \mathrm{~mL} \mathrm{~min}^{-1}$ \\
Sample pump rate & $25 \mathrm{rpm}$ \\
\hline
\end{tabular}

2.4. Sample Digestion Procedure. In this study, wet and MW digestion techniques for fish samples were compared. In both methods, $0.25 \mathrm{~g}$ of reference material and $1 \mathrm{~g}$ of fish sample were employed in duplicate.

In MW digestion procedure, $6 \mathrm{~mL}$ of $65 \% \mathrm{HNO}_{3}$ solution and $2 \mathrm{~mL}$ of $30 \% \mathrm{H}_{2} \mathrm{O}_{2}$ solution were added to the samples and the samples were dissolved in MW system. A program of 32 minutes was used during digestion procedure $(2 \mathrm{~min}$, $250 \mathrm{~W}, 100^{\circ} \mathrm{C} ; 2 \mathrm{~min}, 250 \mathrm{~W}, 100^{\circ} \mathrm{C} ; 5 \mathrm{~min}, 300 \mathrm{~W}, 120^{\circ} \mathrm{C}$; $5 \mathrm{~min}, 550 \mathrm{~W}, 170^{\circ} \mathrm{C} ; 6 \mathrm{~min}, 700 \mathrm{~W} 200^{\circ} \mathrm{C}$; waiting period: $12 \mathrm{~min})$. At the end of the procedure, the solutions were completed to a volume of $10 \mathrm{~mL}$ using ultradistilled water.

In wet digestion procedure, $6 \mathrm{~mL}$ of $65 \% \mathrm{HNO}_{3}$ solution and $2 \mathrm{~mL}$ of $30 \% \mathrm{H}_{2} \mathrm{O}_{2}$ solution were added to a sample of $1 \mathrm{~g}$ and the samples were dissolved at $130^{\circ} \mathrm{C}$ for 4 hours by heating [8]. After the samples were evaporated until they come to an appropriate dryness, they were filtered using filter paper and completed to a volume of $10 \mathrm{~mL}$ using ultradistilled water.

2.5. Validation of the Method. Performance of the method was evaluated in terms of linearity, recovery, and precision. The results obtained for concentrations of $\mathrm{Al}, \mathrm{B}, \mathrm{Cu}, \mathrm{Cr}, \mathrm{Co}$, $\mathrm{Fe}, \mathrm{Mn}, \mathrm{Ni}, \mathrm{Zn}, \mathrm{Cu}, \mathrm{Cr}, \mathrm{Fe}, \mathrm{Ni}$, and $\mathrm{Pb}$ in Fish Protein Certified Reference Material for Trace Metals (DORM-3) were used to validate the method. 
TABLE 2: Certified and observed values $\left(\mu \mathrm{g} \mathrm{g}^{-1}\right)$ of trace elements in DORM-3, $(N=4)$.

\begin{tabular}{|c|c|c|c|c|c|}
\hline Element & Certified value & Microvave digestion & Recovery (\%) & Wet ashing & Recovery (\%) \\
\hline $\mathrm{Al}$ & - & - & - & - & - \\
\hline B & - & - & - & - & - \\
\hline $\mathrm{Cu}$ & $15.5 \pm 0.63$ & $14.9 \pm 0.23$ & 96 & $14.3 \pm 0.26$ & 92 \\
\hline $\mathrm{Cr}$ & $1.89 \pm 0.17$ & $1.80 \pm 0.11$ & 95 & $1.78 \pm 0.14$ & 94 \\
\hline $\mathrm{Fe}$ & $347 \pm 20$ & $338 \pm 12$ & 97 & $330 \pm 16$ & 95 \\
\hline $\mathrm{Mn}$ & - & - & - & - & - \\
\hline $\mathrm{Ni}$ & $1.28 \pm 0.24$ & $1.21 \pm 0.17$ & 95 & $1.19 \pm 0.19$ & 93 \\
\hline $\mathrm{Zn}$ & $51.3 \pm 3.1$ & $50.5 \pm 2.8$ & 98 & $48.7 \pm 3.1$ & 95 \\
\hline
\end{tabular}

TABLE 3: Trace metal contents $\left(\mu \mathrm{g} \mathrm{g}^{-1}\right)$ with microvave and wet ashing methods in Silurus glanis sample (mean \pm S.D., $\left.N=4\right)$.

\begin{tabular}{|c|c|c|c|c|c|c|c|c|c|c|}
\hline \multirow{2}{*}{ Methods } & \multicolumn{10}{|c|}{ Concentrations } \\
\hline & $\mathrm{Al}$ & B & $\mathrm{Ba}$ & $\mathrm{Cr}$ & $\mathrm{Cu}$ & $\mathrm{Fe}$ & $\mathrm{Mn}$ & $\mathrm{Ni}$ & $\mathrm{Sr}$ & $\mathrm{Zn}$ \\
\hline Microvave & $15.9 \pm 1.4$ & $0.20 \pm 0.05$ & $0.44 \pm 0.03$ & $1.64 \pm 0.05$ & $0.35 \pm 0.05$ & $26.5 \pm 1.3$ & $0.33 \pm 0.03$ & $0.70 \pm 0.05$ & $0.80 \pm 0.04$ & $12.9 \pm 2.1$ \\
\hline Wet ashing & $15.1 \pm 0.5$ & $0.17 \pm 0.02$ & $0.39 \pm 0.01$ & $1.58 \pm 0.02$ & $0.31 \pm 0.03$ & $25.7 \pm 1.5$ & $0.30 \pm 0.02$ & $0.66 \pm 0.04$ & $0.75 \pm 0.05$ & $12.2 \pm 2.5$ \\
\hline
\end{tabular}

\section{Results}

Levels of the studied elements were given in dry basis after determination of their concentration by ICP-OES. In order to determinate and compare the digestion procedures including MW and wet, DORM 3 reference material was used. The recoveries of both methods were calculated. The obtained and certified results are presented in Table 2 . Recovery values by MW technique are in the range from 95 to $98 \%$, whereas recovery values by wet digestions are in the range from 92 to $95 \%$. MW technique provided higher and more accurate recovery values for DORM 3 reference material. In order to see the performance of both techniques in real fish samples, muscle tissues of Silurus glanis were digested by MW and wet method, and then trace element levels were determined and the obtained results are given in Table 3. It was found that MW digestion procedure also provides higher values than wet digestion method in real samples. Since MW technique provides an opportunity to work faster and allows lesser amount of analyte lost, it was chosen as the digestion method in this study.

Table 4 shows trace element concentrations in muscle tissues of 17 different fish species, namely, Silurus glanis, Blicca bjoerkna, Capoeta pestai, Cyprinus carpio, Scardinius erythrophthalmus, Mugil cephalus, Barbus capito, Esox lucius, Tinca tinca, Trachurus mediterraneus, Sarda sarda, Mullus barbatus, Engraulis encrasicolus, Gobius niger, Merlangius merlangus, Belone belone and Pomatomus saltatrix. Concentrations of trace elements were found as Al; 6.5-48.5, B; 0.063.30, Ba; 0.09-2.92, Cr; 0.02-1.64, Cu; 0.13-2.28, Fe; 7.28-39.9, Mn; 0.08-11.4, Ni; 0.01-26.1, Sr; 0.17-13.5, and Zn; 11.5-52.9 $\mu \mathrm{gg}^{-1}$.

3.1. Aluminium. Aluminium (Al) is found in large quantities in nature and introduced into living creatures through food chain, particularly through water [15]. Accumulation of $\mathrm{Al}$ in brain cells may cause Parkinson's disease and Alzheimer's disease [16]. The highest and lowest $\mathrm{Al}$ concentrations were determined in the fish species from Sapance Lake. The lowest Al concentration $6.50 \mu \mathrm{g} \mathrm{g}^{-1}$ was found in Tinca tinca species whereas the highest $48.5 \mathrm{\mu gg}^{-1}$ in Esox lucius species. Al concentration in Turkey was reported as $0.02-5.41 \mu \mathrm{gg}^{-1}$ in İskenderun Gulf and Northeastern Mediterranean [17]. An average $\mathrm{Al}$ concentration of $1.35 \mu \mathrm{gg}^{-1}$ was found in a study on fish conducted in France [18]. Daily amount of Al entering a human body along with food in a person living in the city and weighing approximately $70 \mathrm{~kg}$ is $0.01-1.4 \mathrm{mg}$ per $\mathrm{kg}$ of body weight [19].

3.2. Boron. Boron (B) is found in low concentrations in the form of compounds in soil, rocks, and water and introduced into human body by food since it cannot be synthesized in the body. It is released by disassociation of soil and sediments, arising from the environment and human beings. Relatively high concentrations of B are accepted as hazardous for human beings, water birds, and other wild living creatures [20]. The highest and the lowest B concentration in fish samples were $3.30 \mathrm{mg} \mathrm{g}^{-1}$ in Blicca bjoerkna species taken from Sakarya River and $0.06 \mu \mathrm{gg}^{-1}$ in Cyprinus carpio species taken from Çark Stream, respectively. There was no information on B concentration in fish studies in the literature. Daily tolerable amount of boron in nutrition of human beings has been specified as 10-20 mg per $60 \mathrm{~kg}$ of body weight by FAO/WHO [21].

3.3. Barium. Barium (Ba) is found in the form of compounds, not in free form in nature. $\mathrm{Ba}$ ions are found in the waters of lakes, rivers, and stream because barium compounds easily dissolve in water. Thus, barium compounds can be absorbed by organisms living in water and accumulated in their bodies [22]. The lowest Ba concentration determined in fish species was found as $0.09 \mu \mathrm{gg}^{-1}$ in Cyprinus carpio species taken from Sakarya River and the highest $2.92 \mu \mathrm{gg}^{-1}$ in Blicca bjoerkna species taken from Çark Stream. Ba concentrations in fish species taken from Karasu were below detectable level. 


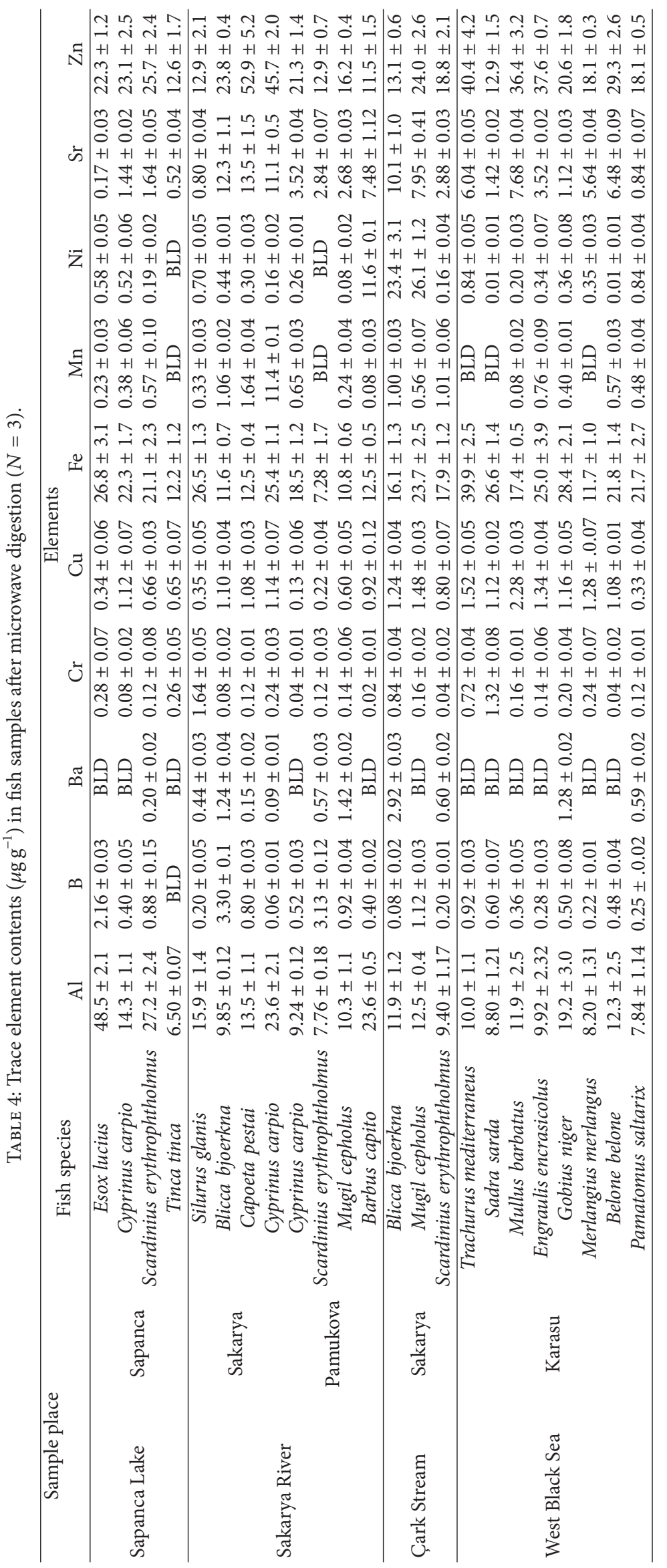


In a study by [23] performed in Turkey, Ba concentration was reported as $3.44-6.96 \mu \mathrm{gg}^{-1}$. However, in a study by [18] performed in France and another one by [11], average Ba concentration was found as $0.065 \mathrm{mg} \mathrm{kg}^{-1}$ and $0.003-2.8$ $\mu \mathrm{gg}^{-1}$, respectively. Daily amount of barium recommended to be taken through food and drinks for an indiviual weighing $60 \mathrm{~kg}$ has been specified as $1.24 \mathrm{mg}$ [24].

3.4. Chromium. Chromium (Cr) is considered as a basic trace element and found in human body, and it is known to control blood sugar and cholesterol level. Exposure of humans to $\mathrm{Cr}$ element is by inhalation, consumption of food containing $\mathrm{Cr}$, and contact with $\mathrm{Cr}$ compounds [25]. According to our results, the lowest $\mathrm{Cr}$ concentration $0.02 \mu \mathrm{g} \mathrm{g}^{-1}$ was determined in Barbus capito species taken from Pamukova and the highest $1.64 \mu \mathrm{gg}^{-1}$ in Silurus glanis species taken from Sakarya River. In general, it could be concluded that $\mathrm{Cr}$ level is low in muscle tissues of 17 fish species investigated in Sakarya. In a previous study, Cr concentration in fish was found in the range of $0.95-1.98 \mu \mathrm{g} \mathrm{g}^{-1}$ [26]. Cr concentration in canned fish was reported as $0.97-1.70 \mu \mathrm{gg}^{-1}$ [27]. There is no information on the maximum $\mathrm{Cr}$ concentration in Turkish Food Codex [28]; however, the ratio of $\mathrm{Cr}$ recommended to be taken by a person of $60 \mathrm{~kg}$ was specified as $50-200 \mu \mathrm{g}$ in the literature [29].

3.5. Copper. Copper $(\mathrm{Cu})$ exists in the nervous system and has an important role during biological electron transfer. Furthermore, $\mathrm{Cu}$ is vital for synthesis of red blood cells. $\mathrm{Cu}$ deficiency may cause blood and nervous system diseases in adults [30]. The lowest $\mathrm{Cu}$ concentration $0.13 \mu \mathrm{gg}^{-1}$ was found in Cyprinus carpio species taken from Pamukova and the highest in Mullus barbatus species taken from Karasu. $\mathrm{Cu}$ concentrations were determined as $0.51-7.05 \mu \mathrm{gg}^{-1}$ in fish studies conducted in Aegean Sea and the Mediterranean [10]. Lower $\mathrm{Cu}$ concentrations $\left(0.090-0.815 \mu \mathrm{gg}^{-1}\right)$ were found by [31]. Cu concentrations in fish species taken from Karasu compared with values of $1.09-2.75 \mu \mathrm{gg}^{-1}$ were reported by [32]. Maximum $\mathrm{Cu}$ concentration allowed by Turkish Food Codex was specified as $20 \mu \mathrm{g} \mathrm{g}^{-1}$ [28]. Therefore, $\mathrm{Cu}$ concentration in muscle tissues in this study is below legal limits. Daily tolerable amount of $\mathrm{Cu}$ on the basis of body weight of $60 \mathrm{~kg}$ was determined as $3 \mathrm{mg}$ by FAO/WHO [33].

3.6. Iron. Iron (Fe) deficiency is most commonly seen particularly in children and women in Turkey as worldwide and causes anemia. Fish is the most important source of Fe for adults and children [34]. At the end of the study, the lowest Fe concentration $7.28 \mu \mathrm{gg}^{-1}$ was found in Scardinius erythrophthalmus species taken from Pamukova and the highest $39.9 \mu \mathrm{g} \mathrm{g}^{-1}$ in Trachurus mediterraneus species taken from Karasu. Higher values were previously found in fish in Turkey, 36.2-110 $\mu \mathrm{gg}^{-1}$ [35] and 5-70.1 $\mathrm{gg} \mathrm{g}^{-1}$ [26]. However, lower values $0.78-4.21$ and $1.55-6.71 \mu \mathrm{gg}^{-1}$ were found by $[31,36]$, respectively, in comparison to $\mathrm{Fe}$ concentrations in various fish species in Sakarya. According to Turkish standards, there is no information on maximum Fe concentration in fish samples [28]. Daily tolerable amount of Fe on the basis of body weight was determined as $48 \mathrm{mg}$ by $\mathrm{FAO} / \mathrm{WHO}$ [33].

3.7. Manganese. Manganese (Mn) is present in all tissues and a vital trace metal for functioning of many organic systems. Mn plays a major role in regulation of blood sugar and reproduction, digestion, and bone growth. Mn also acts as a cellular antioxidant [37]. The lowest Mn concentration of $0.08 \mu \mathrm{gg}^{-1}$ in fish was found in Barbus Carpito taken from Pamukova, Mullus barbatus taken from Karasu and the highest Mn concentration of $11.4 \mu \mathrm{gg}^{-1}$ in Cyprinus carpio species taken from Sakarya River. Reported Mn concentrations from fish studies in Turkey were $2.76-9.10 \mu \mathrm{g} \mathrm{g}^{-1}$ [35] and 1.00-9.40 $\mu \mathrm{gg}^{-1}$ [26]. Lower Mn concentrations were determined in studies carried out in Marmara, Aegean Sea, and the Mediterranean Sea in comparison to Black Sea. There is no information on $\mathrm{Mn}$ concentration in fish samples according to Turkish standards [28]. USA National Sciences Academy (1980) recommends daily $2.5-5 \mathrm{mg}$ per person as the amount of $\mathrm{Mn}$, and daily tolerable amount of manganese based on body weight (according to body weight of $60 \mathrm{~kg}$ ) was suggested as $2-9 \mathrm{mg}$ by WHO [14].

3.8. Nickel. According to investigations, plant based nutrients have higher amounts of nickel (Ni) than animal-based nutrients. Compared to other transition metals, $\mathrm{Ni}$ is a moderately toxic element. Consumption of food with high $\mathrm{Ni}$ content may cause serious problems in observation of many diseases [38]. Inherent amount of $\mathrm{Ni}$ in water is rather low, and in studies performed in the USA, such amount was determined as $4.8 \mu \mathrm{g} \mathrm{L}^{-1}$. The lowest Ni concentration in fish species was $0.01 \mu \mathrm{gg}^{-1}$ in Sarda sarda Belone belone species taken from Karasu and the highest was $26.1 \mu^{\mathrm{gg}^{-1}}$ in Mugil cephalus species taken from Çark Stream. In studies by $[26,39]$ performed in Turkey, average Ni concentration was determined as 1.1-10.2 $\mu \mathrm{g} \mathrm{g}^{-1}$ and 1.2-3.4 $\mu \mathrm{g} \mathrm{g}^{-1}$, respectively. There is no information on Ni concentration in fish samples according to Turkish standards [28]. Daily tolerable amount of $\mathrm{Ni}$ based on body weight of $60 \mathrm{~kg}$ was recommended as $100-300 \mu \mathrm{g}$ by WHO [14].

3.9. Strontium. Strontium (Sr) is a widely available element in nature and recommended for osteoporosis treatment. $\mathrm{Sr}$ is found in respiratory air, soil, drinking water, and nutrients. Introduction of this element into human body takes place mainly by water and foods [40]. The lowest $\mathrm{Sr}$ concentration in fish species was $0.17 \mu \mathrm{gg}^{-1}$ in Exos lucius species taken from Sapanca and the highest was $13.5 \mu \mathrm{gg}^{-1}$ in Capoeta pestai species taken from Sakarya River. In studies reported in the literature, mean concentration of strontium in fish was found as $1.52-16.2 \mu \mathrm{g} \mathrm{g}^{-1}$ [18]. There is no information on maximum $\mathrm{Sr}$ concentration in fish samples according to Turkish standards [28].

3.10. Zinc. Zinc $(\mathrm{Zn})$ is an important trace element in human metabolism and nutrition and plays a major role in functioning of many biochemical processes. $\mathrm{Zn}$ deficiency may cause various conditions and intake of excess $\mathrm{Zn}$ may 
cause side effects [41]. The lowest $\mathrm{Zn}$ concentration in fish species was $11.5 \mu \mathrm{gg}^{-1}$ in Barbus capito species taken from Pamukova and the highest was $52.9 \mu \mathrm{gg}^{-1}$ in Capoeta pestai species taken from Sakarya River. $\mathrm{Zn}$ ratio allowed for fish by Turkish Food Codex is $50 \mu \mathrm{gg}^{-1}$ [28]. Fish species in this study did not show higher levels of $\mathrm{Zn}$ than the legal limit. Average $\mathrm{Zn}$ concentration was found as $11.6-63.5 \mu \mathrm{gg}^{-1}$ in fish studies in Turkey [26]. In other fish studies, [32] reported a $\mathrm{Zn}$ concentration of $4.62-14.6 \mu \mathrm{gg}^{-1}$ and [18] reported a $\mathrm{Zn}$ concentration of $5.6-16 \mu \mathrm{gg}^{-1}$. But, in some studies, high values of $\mathrm{Zn}$, such as $45.0-60.9 \mu \mathrm{gg}^{-1}$ [42], were also detected. Daily tolerable amount of $\mathrm{Zn}$ based on body weight of $60 \mathrm{~kg}$ was specified as $60 \mathrm{mg}$ by FAO/WHO [33].

\section{Conclusions}

While trace levels of some metal ions show toxic effects on humans, some of them are necessary for sustaining metabolism of human body, even though high concentrations of all metal ions can pose a threat to human health. Therefore, heavy metal ion levels in food and water consumed by human beings are important. In this study, levels of some elements were determined in various fish species living in lakes, rivers, streams, and sea in Sakarya. Wet and MW digestion techniques were used to prepare the samples for analysis. MW method was chosen as the most appropriate method since it takes less time and causes lesser amount of analyte lost. Trace levels of elements were determined successfully in fish samples using ICP-OES technique. Metal concentrations were generally found to be lower than the limit values specified by Turkish Food Codex (TFC), Food and Agriculture Organization (FAO), and World Health Organization (WHO).

In terms of heavy metal content, it could be concluded that there is no risk in consumption of fish collected from Sakarya region in Sakarya River, Çark Stream, Sapanca Lake, and Western Black Sea.

\section{Conflict of Interests}

The authors declare that there is no conflict of interests regarding the publication of this paper.

\section{Acknowledgment}

The authors are grateful to Scientific Research Project of Sakarya University (Project no: 2012-02-04-044) for financial supports.

\section{References}

[1] L. Bat, M. Sezgin, F. Üstün, and F. Şahin, "Heavy metal concentrations in ten species of fishes caught in sinop coastal waters of the Black Sea, Turkey," Turkish Journal of Fisheries and Aquatic Sciences, vol. 12, pp. 371-376, 2012.

[2] S. Sivrikaya, H. Altundag, M. Zengin, and M. Imamoglu, "Separation, preconcentration, and recovery of $\mathrm{Pd}(\mathrm{II})$ ions using newly modified silica gel with bis(3-aminopropyl) amine,"
Separation Science and Technology, vol. 46, no. 13, pp. 20322040, 2011.

[3] H. Altundag and M. S. Dundar, "Determination of thallium after preconcentration on amberlite IR-120 by ICP-MS," Fresenius Environmental Bulletin, vol. 18, no. 1, pp. 98-101, 2009.

[4] F. Aydemir, H. Altundag, and M. Imamoglu, "Removal of $\mathrm{Cr}$ (VI) from aqueous solution by hazelnut husk carbon," Fresenius Environmental Bulletin, vol. 21, no. 11c, pp. 3589-3594, 2012.

[5] H. Özparlak, G. Arslan, and E. Arslan, "Determination of some metal levels in muscle tissue of nine fish species from Beyşehir Lake, Turkey," Turkish Journal of Fisheries and Aquatic Sciences, vol. 4, pp. 761-770, 2012.

[6] M. S. Dundar and H. Altundag, "Heavy metal determinations of house dusts in Adapazari City, Turkey after Earthquake," Trace Elements and Electrolytes, vol. 19, no. 2, pp. 55-58, 2002.

[7] H. Altundag, M. S. Dundar, S. Doganc1, M. Celik, and M. Tuzen, "The use of a sequential extraction procedure for heavy metal analysis of house dusts by atomic absorption spectrometry," Journal of AOAC International, vol. 96, no. 1, pp. 166-170, 2013.

[8] H. Altundag and M. Tuzen, "Comparison of dry, wet and microwave digestion methods for the multi element determination in some dried fruit samples by ICP-OES," Food and Chemical Toxicology, vol. 49, no. 11, pp. 2800-2807, 2011.

[9] C. Cahu, P. Salen, and M. de Lorgeril, "Farmed and wild fish in the prevention of cardiovascular diseases: assessing possible differences in lipid nutritional values," Nutrition, Metabolism and Cardiovascular Diseases, vol. 14, no. 1, pp. 34-41, 2004.

[10] M. Turkmen, A. Turkmen, Y. Tepe, Y. Tore, and A. Ates, "Determination of metals in fish species from Aegean and Mediterranean Seas," Food Chemistry, vol. 113, no. 1, pp. 233-237, 2009.

[11] R. J. Medeiros, L. M. G. dos Santos, A. S. Freire et al., "Determination of inorganic trace elements in edible marine fish from Rio de Janeiro State, Brazil," Food Control, vol. 23, no. 2, pp. 535$541,2012$.

[12] M. Dağtekin and O. Ak, "Doğu karadeniz bölgesinde su ürünleri tüketimi, ihracat ve ithalat potansiyeli," SUMAE Yunus Araştırma Bülteni, vol. 7, no. 3, pp. 14-17, 2007.

[13] TUIK, 2011, http://www.tuik.gov.tr/Start.do .

[14] World Health Organization, Quality Directive of Potable Water, vol. 197, WHO, Geneva, Switzerland, 2nd edition, 1994.

[15] L. Gerhardsson, A. Oskarsson, and S. Skerfving, "Acid precipitation-effects on trace elements and human health," Science of the Total Environment, vol. 153, no. 3, pp. 237-245, 1994.

[16] I. Narin, M. Tuzen, and M. Soylak, "Aluminium determination in environmental samples by graphite furnace atomic absorption spectrometry after solid phase extraction on amberlite xad1180/pyrocatechol violet chelating resin," Talanta, vol. 63, no. 2, pp. 411-418, 2004.

[17] A. Türkmen, M. Türkmen, Y. Tepe, and I. Akyurt, "Heavy metals in three commercially valuable fish species from İskenderun Bay, Northern East Mediterranean Sea, Turkey," Food Chemistry, vol. 91, no. 1, pp. 167-172, 2005.

[18] T. Guérin, R. Chekri, C. Vastel et al., "Determination of 20 trace elements in fish and other seafood from the French market," Food Chemistry, vol. 127, no. 3, pp. 934-942, 2011.

[19] R. Ranau, J. Oehlenschläger, and H. Steinhart, "Aluminium levels of fish fillets baked and grilled in aluminium foil," Food Chemistry, vol. 73, no. 1, pp. 1-6, 2001.

[20] C. Darcan and M. Kahyaoğlu, "The effect of some boron derivatives on kanamycin resistance and survival of E. coli and P. aeruginosa in lake water," Biomedical and Environmental Sciences, vol. 25, no. 4, pp. 476-482, 2012. 
[21] FAO, Water Quality for Agriculture Irrig and Drainage Rome 81, 29 pp., 1985.

[22] A. Ghaemi, M. Torab-Mostaedi, H. Ghassabzadeh, and M. Ghannadi-Maragheh, "Removal of strontium and barium from aqueous solutions by adsorption onto expanded Perlite," Canadian Journal of Chemical Engineering, vol. 89, no. 5, pp. 12471254, 2011.

[23] F. Yilmaz, N. Özdemir, A. Demirak, and A. L. Tuna, "Heavy metal levels in two fish species Leuciscus cephalus and Lepomis gibbosus," Food Chemistry, vol. 100, no. 2, pp. 830-835, 2007.

[24] IPCS Barium, International Programme on Chemical Safety, Environmental Health Criteria 107, World Health Organization, Geneva, Switzerland, 1990.

[25] A. M. Rousse, "Chrome et syndrome métabolique: chromium and the metabolic syndrome," Médecine des Maladies Métaboliques, vol. 3, no. 5, pp. 483-485, 2009.

[26] D. Mendil, Ö. F. Ünal, M. Tüzen, and M. Soylak, "Determination of trace metals in different fish species and sediments from the Yesilırmak in Tokat, Turkey," Food and Chemical Toxicology, vol. 48, no. 5, pp. 1383-1392, 2010.

[27] M. Tuzen and M. Soylak, "Determination of trace metals in canned fish marketed in Turkey," Food Chemistry, vol. 101, no. 4, pp. 1378-1382, 2007.

[28] Anonymous Regulation of setting maximum levels for certain contaminants in foodstuffs Official Gazette October 16: Iss: 24908, 2002.

[29] RDA, Recommended Dietary Allowance, National Academic Press, Washington, DC, USA, 10th edition, 1989.

[30] M. H. Dabbaghmanesh, N. M. Salehi, J. Siadatan, and G. R. Omrani, "Copper concentration in a healthy urban adult population of Southern Iran Mohammad," Biological Trace Element Researc, vol. 144, no. 1-3, pp. 217-224, 2011.

[31] M. Ashraf, J. Tariq, and M. Jaffar, "Contents of trace metals in fish, sediment and water from three freshwater reservoirs on the Indus River, Pakistan," Fisheries Research, vol. 12, no. 4, pp. 355364, 1991.

[32] J. Aucoin, R. Blanchard, C. Billiot et al., "Trace metals in fish and sediments from Lake Boeuf, southeastern Louisiana," Microchemical Journal, vol. 62, no. 2, pp. 299-307, 1999.

[33] Joint FAO/WHO Expert Committee on Food Additives, "Summary and conclusions," in Proceedings of the 53rd Meetting, Rome, Italy, June 1999.

[34] T. Walter, P. Pino, F. Pizarro, and B. Lozoff, "Prevention of irondeficiency anemia: comparison of high- and low-iron formulas in term healthy infants after six months of life," Journal of Pediatry, vol. 132, no. 4, pp. 635-640, 1998.

[35] M. Tuzen, "Toxic and essential trace elemental contents in fish species from the Black Sea, Turkey," Food and Chemical Toxicolog, vol. 47, no. 8, pp. 1785-1790, 2009.

[36] J. Tariq, M. Jaffar, and M. Ashraf, "Trace metal concentration, distribution and correlation in water, sediment and fish from the Ravi River, Pakistan," Fisheries Research, vol. 19, no. 1-2, pp. 131-139, 1994.

[37] J. L. Aschner and M. Aschner, "Nutritional aspects of manganese homeostasis," Molecular Aspects of Medicine, vol. 26, no. 4-5, pp. 353-362, 2005.

[38] D. Schiavino, E. Nucera, C. Alonzi et al., "A clinical trial of oral hyposensitization in systemic allergy to nickel," International Journal of Immunopathology and Pharmacology, vol. 19, no. 3, pp. 593-600, 2006.
[39] D. Uluözlü, O. D. Mendil, E. Hasdemir, M. Tüzen, H. Sari, and M. Suicmez, "Determination of trace metal levels in seven fish species in lakes in Tokat, Turkey," Food Chemistry, vol. 90, no. 1-2, pp. 175-179, 2005.

[40] F. Özdemir and E. Esen, "Strontium and osteoporosis," World of Osteoporosis, vol. 10, no. 2, pp. 77-79, 2004.

[41] H. Scherz and E. Kirchhoff, "Trace elements in foods: zinc contents of raw foods - a comparison of data originating from different geographical regions of the world," Journal of Food Composition and Analysis, vol. 19, no. 5, pp. 420-433, 2006.

[42] J. Park and B. J. Presley, "Trace metal contamination of sediments and organisms from the swan lake area of Galveston bay," Environmental Pollution, vol. 98, no. 2, pp. 209-221, 1997. 

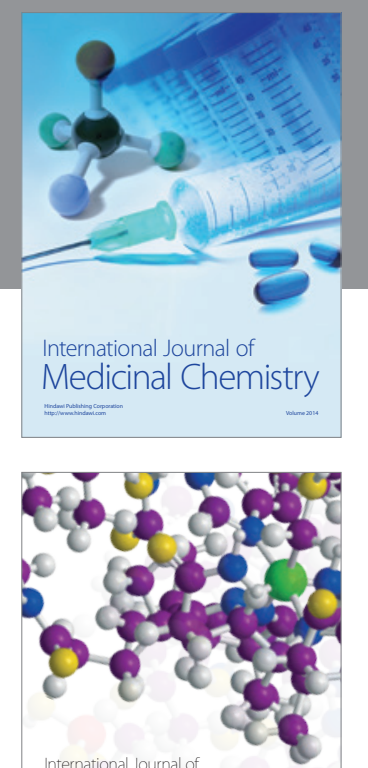

\section{Carbohydrate} Chemistry

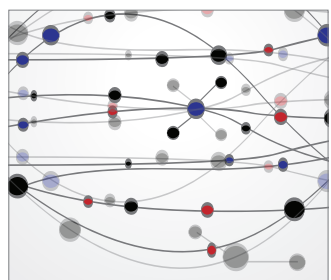

The Scientific World Journal
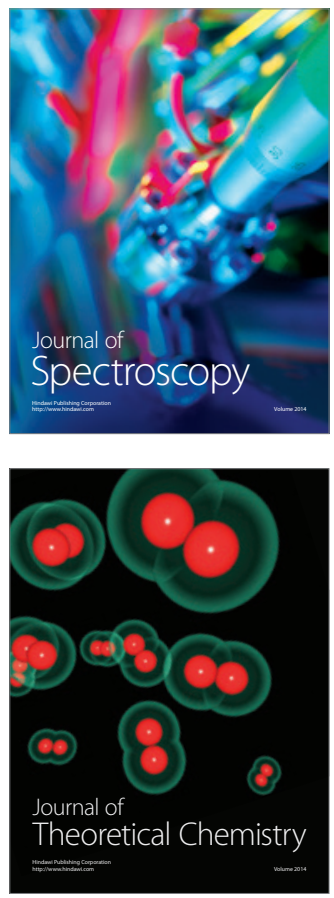
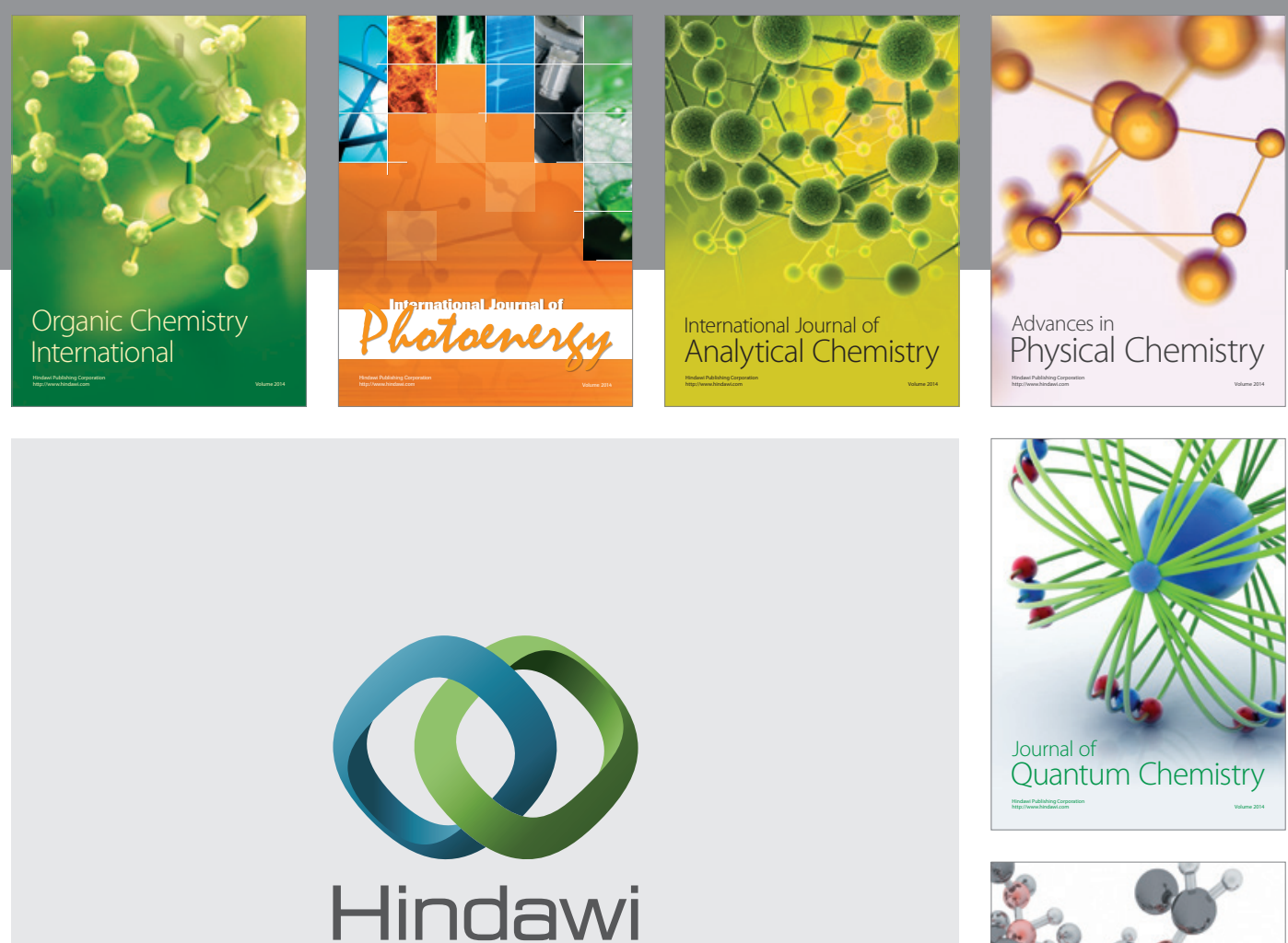

Submit your manuscripts at

http://www.hindawi.com

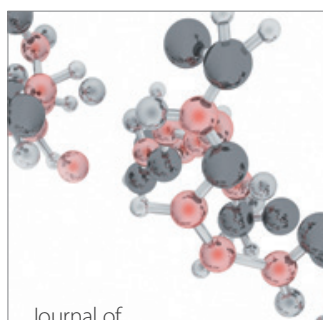

Analytical Methods

in Chemistry

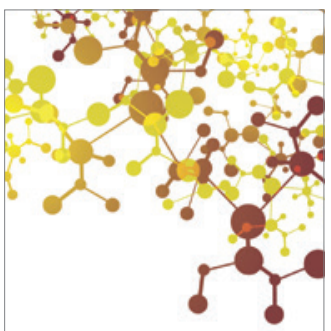

Journal of

Applied Chemistry

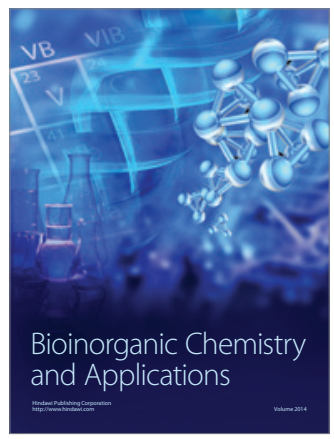

Inorganic Chemistry
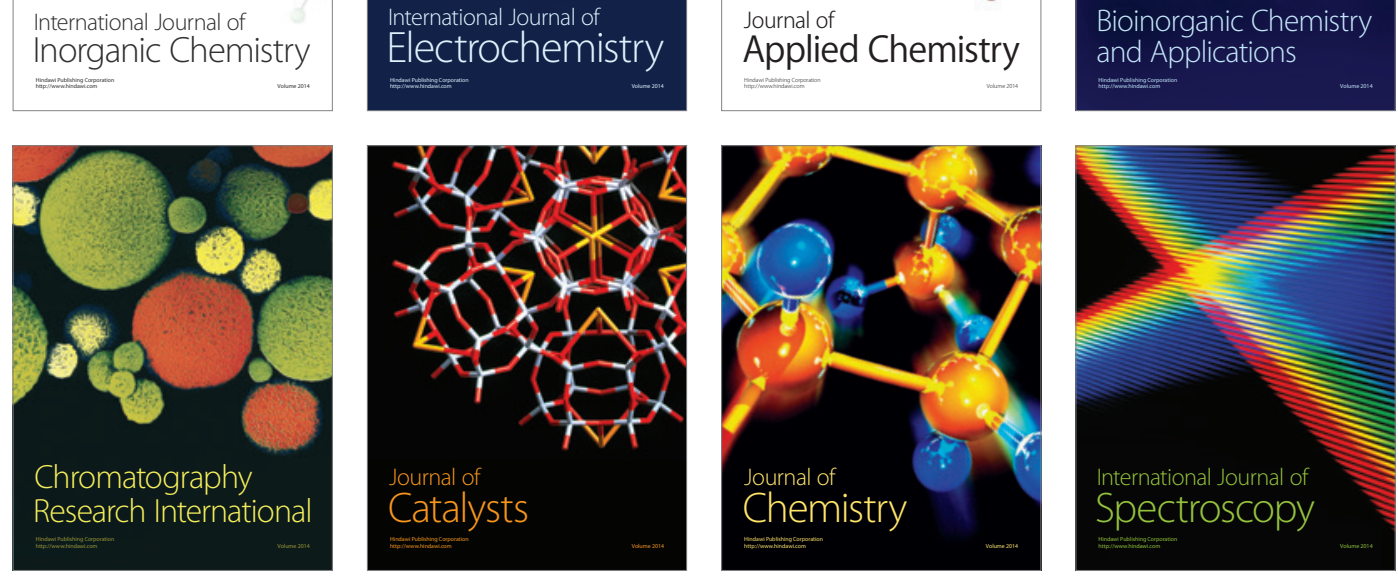